\title{
A comparison of the effects of raw and heated soya-bean meal in diets for germ-free and conventional chicks
}

\author{
By MARIE E. COATES AND D. HEWIT"T \\ National Institute for Research in Dairying, Shinfield, Reading \\ AND P. GOLOB* \\ Brunel University, London
}

(Received 23 May 1969-Accepted I 8 fuly 1969)

\begin{abstract}
I. Chicks were reared to 3 weeks in a germ-free or conventional environment on diets containing $50 \%$ raw or heated soya-bean meal. Body-weights and pancreas weights were determined and the proteolytic and amylolytic enzymes in the pancreas were measured. In one experiment the contents of the intestinal tract were analysed for their content of nitrogenous compounds.

2. The growth of chicks given raw soya was depressed below that of controls given heated soya, and the growth depression was significantly greater in the conventional compared with the germ-free environment.

3. The pancreases of chicks given raw soya were significantly larger than those given heated soya. The degree of enlargement was similar in both environments. The concentration of $\alpha$-amylase was lower in the enlarged pancreases, but the total amount per pancreas was similar to that in the normal pancreases. Conversely, the concentration of proteolytic enzymes was the same or greater in the enlarged pancreases, which had significantly greater total content of proteases than did the normal pancreases.

4. There was evidence of impaired protein digestion in the birds given the raw soya diets. Their gut contents contained larger amounts of insoluble matter, with higher nitrogen content, and the soluble fraction contained more nitrogen present as 'protein', with correspondingly less 'peptide' and 'amino acid', than did similar samples from birds given heated soya. No differences were observed in this respect between germ-free and conventional birds.

5. It was concluded that the gut microflora exacerbated the growth-depressing effect on chicks of raw soya meal. Possible explanations are advanced.
\end{abstract}

The unsatisfactory nature of raw soya beans and some other legumes as ingredients of animal diets is well known. They have been shown to contain trypsin inhibitors and toxic factors that are destroyed by heat. Chicks given raw soya-bean meal grow poorly and develop enlarged pancreases, but after heat treatment the meal, which is an excellent source of protein, supports good growth and normal pancreas development. Although the inhibition of trypsin, with consequent impairment of protein digestion, may be partly responsible for the poor performance on diets containing the raw meal it does not account for the full severity of the effects (see review by Liener, 1962). In a brief communication Miller \& Coates (1966) reported that diets containing raw soya meal supported considerably better growth of germ-free chicks than of their corresponding conventional controls, and postulated that the microflora of the gastrointestinal tract plays an important role in the growth-depressing action. The work reported here confirms and extends these observations. In addition, the end-products

* Present address: Department of Physiology, School of Medicine, Leeds. 
of digestion of raw and heated soya in the presence and absence of a microflora have been investigated, and the enzyme content of the normal and enlarged pancreases has been measured.

\section{MATERIALS AND METHODS}

\section{Chicks and experimental treatment}

Chicks of the Rhode Island Red $\times$ Light Sussex cross, bred on the Institute farm, were used. Germ-free birds were produced and maintained as described by Coates, Fuller, Harrison, Lev \& Suffolk ( 1963 ). The eggs were disinfected on the I 8 th day of incubation and passed into Gustafsson stainless steel isolators. For the corresponding conventional controls, eggs from the same batch were similarly disinfected and then returned to a commercial incubator to hatch. The chicks were allotted to the experimental treatments at I day of age, with the sexes distributed as evenly as possible among the groups. The germ-free birds were housed in groups of four or five in stainless steel cages within the isolators; the conventional birds were similarly housed in a controlled-environment room in which the temperature, humidity and lighting conditions could be adjusted to match those within the isolators. They were weighed at weekly intervals, and the experiments lasted for up to 3 weeks. Several sterility checks (Coates et al. 1963) were made on the germ-free chicks during the course of each experiment.

In the experiment with conventional chicks only, the eggs were incubated and hatched in the standard way, with no disinfection treatment. The birds were housed in groups of ten in electrically-heated tier brooders.

Altogether, four experiments were done. The first was a pilot experiment with conventional chicks only. Groups of about twenty birds were reared to 3 weeks on the experimental diet with raw or heated soya meal, with or without a supplement of $0.3 \%$ DL-methionine. Total proteolytic, chymotrypsin, trypsin and amylolytic activities were determined in the pancreases of five birds from each treatment. In Expts 2-4, groups of birds were reared to 3 weeks on the diets with raw and heated soya meal in germ-free or conventional environments. The intestinal contents from five birds in each treatment in Expt 2 were analysed for soluble and insoluble nitrogenous constituents. Trypsin and $\alpha$-amylase activities were determined in the pancreases from all birds in Expt 4 .

At the end of each experiment the birds were killed by gassing with ether and the pancreases were removed and weighed.

\section{Diets}

Diet and water were freely available at all times. A diet of purified ingredients, containing $50 \%$ raw or heated soya meal, was used. The details of its composition are given in Table $\mathrm{r}$. As mixed, it was too fine to be acceptable to the birds, and was converted into granules by moistening with water, pressing through a coarse sieve and drying overnight in a stream of air at $40^{\circ}$. In all diets to be sterilized, the vitamin supplements were increased to four times normal to meet possible losses encountered during the sterilization process. 
The raw soya meal was either White Soya Grits No. 5, obtained from Central Soya, Decatur, Indiana, or a meal prepared in the laboratory. For the latter, soya beans (U.S. No. 2; British Oil and Cake Mills Ltd, London, $\mathrm{EC}_{4}$ ) were ground to a fine meal. The meal was defatted by adding it, in $4 \mathrm{~kg}$ quantities, to cold light petroleum (b.p. $40-60^{\circ}$ ) in a glass column, $115 \mathrm{~cm}$ high by $10.5 \mathrm{~cm}$ internal diameter. It was allowed to settle and then 17.51 . of the solvent was run through. To aid final evaporation of the solvent this was followed by $2.5 \mathrm{l}$. of a lighter grade of light petroleum (b.p. below $40^{\circ}$ ). The meal was then spread on trays and exposed to a current of cold air until the solvent was removed. The heated meals were prepared by autoclaving the defatted raw material, spread on shallow steel trays, at $12 \mathrm{I}^{\circ}\left(\mathrm{I} 5 \mathrm{lb} / \mathrm{in}^{2}\right)$ for $\mathrm{I} 5 \mathrm{~min}$.

\section{Table r. Percentage composition of the diet}

$\begin{array}{lllr}\text { Salt mixture* } & 6.0 & \text { B-vitamin triturate } & 0.2 \\ \text { Glycine } & 0.5 & \text { Maize oil } & 5.0 \\ \text { DL-methionine } & 0.15 & \text { Soya-bean meal } & 50 \\ \text { Inositol } & 0.1 & \text { Maize starch to } & 100 \\ \text { Choline chloride } & 0.15 & & \end{array}$

* Contained (parts by weight): $\mathrm{CaCO}_{3} 2566, \mathrm{CaHPO}_{4} .2 \mathrm{H}_{2} \mathrm{O} 2566, \mathrm{KH}_{2} \mathrm{PO}_{4} 2000, \mathrm{NaCl} \mathrm{I}_{300}$, $\mathrm{MgSO}_{4} \cdot 4 \mathrm{H}_{2} \mathrm{O} 400, \mathrm{FeSO}_{4} \cdot 7 \mathrm{H}_{2} \mathrm{O}$ 100, $\mathrm{MnSO}_{4} \cdot 4 \mathrm{H}_{2} \mathrm{O} 4 \cdot 0, \mathrm{ZnSO}_{4} \cdot 7 \mathrm{H}_{2} \mathrm{O} 2 \cdot 0, \mathrm{CuSO}_{4} \cdot{ }_{5} \mathrm{H}_{2} \mathrm{O} 2 \cdot 4, \mathrm{KI}{ }_{5} \cdot 6$.

$\dagger$ To provide, per $100 \mathrm{~g}$ diet: biotin $20 \mu \mathrm{g}$, pteroylmonoglutamic acid $75 \mu \mathrm{g}$, thiamine hydrochloride $300 \mu \mathrm{g}$, pyridoxol hydrochloride $400 \mu \mathrm{g}$, riboflavine $600 \mu \mathrm{g}$, calcium pantothenate $\mathrm{I} \cdot 5 \mathrm{mg}$, nicotinic acid $4 \mathrm{mg}$, glucose to $200 \mathrm{mg}$. Cyanocobalamin solution (100 $\mu \mathrm{g} / \mathrm{ml}$ ) was added to provide $2 \mu \mathrm{g}$ cyanocobalamin in each $100 \mathrm{~g}$ diet.

I Containing in $5 \mathrm{~g}$ : cholecalciferol 160 i.u., $\alpha$-tocopheryl acetate I $\mathrm{mg}$ and menaphthone $500 \mu \mathrm{g}$. Rovimix A (Roche Products Ltd, Welwyn) was added to supply I $700 \mathrm{i} . \mathrm{u}$. vitamin A/100 g diet.

$\S$ White Soya Grits No. 5 in Expts 1 and 2. Laboratory-prepared meal (see above) in Expts 3 and 4.

For experiments involving germ-free chicks the diets were sealed in $35^{\circ} \mathrm{g}$ quantities in plastic bags and sterilized by $\gamma$-irradiation at $5 \mathrm{Mrad}$ from a ${ }^{60} \mathrm{Co}$ source. The sterilized diet was fed to the conventional controls as well as to the germ-free birds. Previous work has shown that the response of the birds to the diet before and after sterilization was not measurably different (Miller \& Coates, x966).

\section{Collection of contents from the alimentary tract}

Degradation of the mucosa lining the alimentary tract occurs very rapidly after death; hence, in order to collect the contents uncontaminated with mucosal cell debris, it was necessary to wash out the tract in the live bird. The chick was anaesthetized with ether and an incision was made in the abdomen to expose most of the intestine. A ligature was placed at the pylorus, and a glass cannula was inserted below it, leading into the proximal end of the duodenum. A second ligature was tied at the point of entry of the bile duct and another cannula, fitted with a plastic tube leading into a plastic collecting vessel standing in ice, was inserted into the distal end of the duodenum. Normal saline $\left(0.85 \%\right.$, w/v) at $38^{\circ}$ was passed through the duodenal loop until the fluid emerging from the lower end was clear. The two cannulas were removed and the process was repeated in the jejunum, i.e. from the point of entry of the bile duct to the yolk stalk, and again in the ileum, from the yolk stalk to the ileo-caecal junction. The contents of the caecums and colon were then collected by means of a 
cannula inserted into the rectum, warm saline from a syringe being introduced through the tips of the caecums. The washing-out of contents was usually achieved with about $20 \mathrm{ml}$ saline in the duodenum and the caecums and colon; up to $50 \mathrm{ml}$ was necessary to clear the jejunum and ileum.

\section{Analysis of gut contents}

Immediately after collection, the contents from the different parts of the alimentary tract were centrifuged at $\mathrm{r} 200 \mathrm{~g}$ for $30 \mathrm{~min}$ at $5^{\circ}$. The supernatant fraction was decanted and the residue resuspended in $10 \mathrm{ml}$ distilled water. After further centrifuging for $10 \mathrm{~min}$ the washing water was added to the first supernatant fraction. The insoluble residue was transferred to a tared aluminium dish and dried overnight at $105^{\circ}$. After weighing, the dried samples from each treatment were pooled. The supernatant fractions were individually freeze-dried; the dried residues from each treatment were then combined, in order to provide a large enough sample for analysis. The combined samples of insoluble and soluble fractions were analysed for nitrogen after semi-micro digestion on a Technicon auto-analyser by a modification of the method described in Technicon Methodology Sheet no. N-36 (Technicon Instrument Corporation, Chertsey, England).

The pooled soluble residues were redissolved in $0.02 \mathrm{M}-\mathrm{NaH}_{2} \mathrm{PO}_{4} \cdot 2 \mathrm{H}_{2} \mathrm{O}$ buffer at $\mathrm{pH} 7.6$ containing $0 \cdot 1 \mathrm{M}-\mathrm{NaCl}$, to give a concentration of $2 \mathrm{mg} \mathrm{N} / 5 \mathrm{ml}$, and then fractionated on Sephadex gel filtration medium (G-25, medium bead form, particle diameter $5^{0-1} 5^{\circ} \mu \mathrm{m}$; Pharmacia, Uppsala, Sweden). The gel was packed to a height of $60 \mathrm{~cm}$ in a column of internal diameter $2.6 \mathrm{~cm}$, calibrated as described by Ford $\left(1_{96}\right)$. A $5 \mathrm{ml}$ portion of the sample was applied to the column and eluted with the phosphate buffer at a flow rate of $\mathrm{I} 60 \mathrm{ml} / \mathrm{h}$. Cytochrome $c$, glucagon and a mixture of amino acids were used as markers to show that soluble proteins and peptides of molecular weight greater than about 4000 were eluted between 120 and $140 \mathrm{ml}$, peptides of molecular weight greater than $25^{\circ}$ but less than 4000 between $15^{\circ}$ and $200 \mathrm{ml}$ and free amino acids between 210 and $230 \mathrm{ml}$.

One $\mathrm{ml}$ of each fraction was heated in an autoclave with $2 \mathrm{ml}$ of $6 \mathrm{~N}-\mathrm{HCl}$ for $3 \mathrm{~h}$ at $120^{\circ}$. To each hydrolysate were added $2 \cdot 4 \mathrm{ml} \mathrm{N}-\mathrm{NaOH}$ and $\mathrm{I}$ ml of $4 \mathrm{~N}$-sodium acetate buffer solution of $\mathrm{pH}_{5} \cdot 5$, and the whole was made up to $10 \mathrm{ml}$ with water. Of this, I $\mathrm{ml}$ was taken for the estimation of $\alpha$-amino $\mathrm{N}$, by reaction with the modified ninhydrin reagent of Moore \& Stein (1954). A standard curve was prepared with graded concentrations of leucine and the results were expressed in terms of 'leucine equivalent'.

\section{Enzyme extraction}

\section{Assays of pancreatic enzymes}

Proteolytic enzymes. In Expt I samples of each pancreas, approximately o I g, were homogenized in a Potter-Elvehjem homogenizer with a Teflon plunger (Arthur H. Thomas and Co., Philadelphia, Pa., I9105, USA) in $2 \mathrm{ml} 0.0$ I M-tris (hydroxymethyl)amino methane, $0.03 \mathrm{M}-\mathrm{CaCl}_{2}$ buffer, $\mathrm{pH} 7.5$, for $5 \mathrm{~min}$ at $0^{\circ}$. The homogenates were diluted with buffer to give a final concentration of $2 \mathrm{mg}$ pancreas $/ \mathrm{ml}$. 
In Expt 4 whole pancreases were homogenized in $0.15 \mathrm{M}-\mathrm{NaCl}$ containing $0.1 \%$ $(w / v)$ Triton X-10o for $3 \mathrm{~min}$ at $0^{\circ}$ in an MSE homogenizer at maximum speed. The homogenates were diluted with the saline to $50 \mathrm{ml}$. To $4 \mathrm{ml}$ of the homogenates, I $\mathrm{ml} 0.05 \mathrm{M}$-tris(hydroxymethyl)amino methane, $0.15 \mathrm{M}-\mathrm{CaCl}_{2} \cdot 2 \mathrm{H}_{2} \mathrm{O}$ buffer, $\mathrm{pH} 7 \cdot 8$, was added and the mixture centrifuged at $1000 \mathrm{~g}$ for $5 \mathrm{~min}$ at $0^{\circ}$. The supernatant fraction was retained for trypsin assay.

$\alpha$-Amylase. In Expt I pancreas samples were homogenized in $5 \mathrm{ml} \mathrm{o}$ ० о $\mathrm{M}-\mathrm{K}_{2} \mathrm{HPO}_{4}$, $0.85 \%,(\mathrm{w} / \mathrm{v}) \mathrm{NaCl}$ buffer, $\mathrm{pH} 6.5$, and then centrifuged at $10000 \mathrm{~g}$ at $\mathrm{o}^{\circ}$. The supernatant fractions were retained and diluted with the buffer to contain the extract from approximately $25 \mu \mathrm{g}$ pancreas $/ \mathrm{ml}$.

In Expt 4 samples of the homogenates, described above, were centrifuged at $1000 \mathrm{~g}$ for $5 \mathrm{~min}$ at $0^{\circ}$, and the supernatant fractions retained for assay.

\section{Enzyme assay}

Total proteolytic activity. Total proteolytic activity was estimated by measuring the extent of casein digestion in Io min at $37^{\circ}$ at $\mathrm{pH} 7.5$, based on the method of Kunitz (1947). The results are expressed as $\mathrm{m}$-moles tyrosine released under the conditions of the experiment.

$\alpha$-Chymotrypsin and trypsin. The methods used were developed from those of Schwert \& Takenaka (1955). In Expt I the pancreatic tissue homogenates, prepared as described above, were filtered through Whatman paper no. 542. The filtrate was incubated for $30 \mathrm{~min}$ at $37^{\circ}$ with an equal volume of $0.02 \%(\mathrm{w} / \mathrm{v})$, entero-peptidase (Enterokinase; Nutritional Biochemicals, Cleveland, Ohio) in 0.0 I M-tris(hydroxymethyl)amino methane, $0.03 \mathrm{M}-\mathrm{CaCl}_{2}$ buffer of the appropriate $\mathrm{pH}(8.2$ for the chymotrypsin assay and 7.5 for the trypsin assay). The enzyme preparations were incubated with $N$-acetyl-L-tyrosine ethyl ester monohydrate (ATEE) and $N$-benzoyl-L-arginine ethyl ester (BAEE), specific substrates for $\alpha$-chymotrypsin and trypsin respectively. The enzyme reactions were followed by differential spectrophotometry after the addition of $0.5 \mathrm{ml}$ of the enzyme preparations to $3 \mathrm{ml}$ of the respective substrates in cuvettes. The substrate concentrations were $0.25 \mathrm{~mm}$-ATEE in buffer, $\mathrm{pH} 8.2$, and $0.5 \mathrm{~m}$-moles BAEE in buffer, $\mathrm{pH} 7 \cdot 5$. Hydrolysis of the substrates was followed by measuring the decrease in extinction at $236 \mathrm{~nm}$ for ATEE and the increase in extinction at $254 \mathrm{~nm}$ for BAEE. In both assays optical density readings were taken every $30 \mathrm{sec}$. A unit of enzyme activity was defined as a change in optical density of $\mathrm{I} \cdot 0$ per min. Pure chymotrypsin and trypsin had activities of $244^{\circ}$ and 3500 units per $\mathrm{mg}$, respectively.

In Expt 4 the supernatant fractions were incubated for $\mathrm{I} h$ at $37^{\circ}$ with an equal volume of enterokinase solution $(0.05 \%, \mathrm{w} / \mathrm{v})$. Suitable portions of the activated enzyme preparation, $0 \cdot 2-0.4 \mathrm{ml}$, were added to $3 \mathrm{ml} 0 \cdot 00 \mathrm{I} \mathrm{M-BAEE}$ and the increase in optical density was recorded on a recording spectrophotometer (Optica model $\left.\mathrm{CF}_{4} \mathrm{DR}\right)$. In these conditions pure trypsin contained 8680 units of activity per mg.

$\alpha$-Amylase activity. The method used in Expt I was adapted from Dollar (1959). The diluted extract ( $\mathrm{I} \mathrm{ml}$ ) was incubated with $4 \mathrm{ml}$ of $0.01 \mathrm{M}-\mathrm{K}_{2} \mathrm{HPO}_{4}, 0.85 \%, \mathrm{w} / \mathrm{v} \mathrm{NaCl}$, $\mathrm{pH} \mathrm{6.5}$, buffer and I $\mathrm{ml}$ of $\mathrm{I} \%(\mathrm{w} / \mathrm{v})$ soluble starch solution at $37^{\circ}$ for $\mathrm{I} 5 \mathrm{~min}$. The 
reaction was stopped by adding $2 \mathrm{ml} 0.3 \mathrm{~N}-\mathrm{Ba}(\mathrm{OH})_{2}$ and $2 \mathrm{ml} 5 \% \mathrm{ZnSO}_{4}$ and the protein precipitate was filtered off (Whatman paper no. 542). The reducing sugars produced were estimated colorimetrically. One $\mathrm{ml}$ of the filtrate was boiled for $10 \mathrm{~min}$ with $2 \mathrm{ml}$ copper reagent (Somogyi, 1952). After cooling, $2 \mathrm{ml}$ arseno-molybdate reagent (Nelson, I944) was added and the solutions shaken to remove carbon dioxide. The volume was adjusted to $25 \mathrm{ml}$ with distilled water and the extinction of the solutions was read at $725 \mathrm{~nm}$. The activity of the homogenates was expressed in terms of the reducing capacity of maltose. A unit of amylase activity was defined as the amount of enzyme releasing reducing groups equivalent to i $\mu \mathrm{g}$ maltose $/ \mathrm{h}$.

The method used in Expt 4 was that of Howard \& Yudkin (1963) except that the period of incubation with the starch solution was increased from $10 \mathrm{~min}$ to $30 \mathrm{~min}$. The activity of the homogenates was expressed in terms of the amount of starch hydrolysed per h.

\section{RESULTS}

\section{Chick growth and pancreas weight}

The mean body-weights and pancreas weights of the birds in all four experiments are given in Table 2 . The results were examined by analysis of variance, using group means. In Expt I, with conventional chicks only, the body-weight was significantly, $(0.001<P<0.01)$ depressed in the birds given the raw soya diets, and the pancreas

Table 2. Effect of raw and heated soya-bean meal on mean body-weight $(g)$ and mean pancreas weight ( $\mathrm{g} / \mathrm{1} 00 \mathrm{~g}$ body-weight) of germ-free and conventional chicks at 3 weeks of age

\begin{tabular}{|c|c|c|c|c|c|c|}
\hline \multirow[b]{2}{*}{$\begin{array}{c}\text { Expt } \\
\text { no. }\end{array}$} & \multirow{2}{*}{$\begin{array}{l}\text { No. of } \\
\text { birds/ } \\
\text { treatment }\end{array}$} & \multirow[b]{2}{*}{ Type of soya } & \multicolumn{2}{|c|}{ Germ-free chicks } & \multicolumn{2}{|c|}{ Conventional chicks } \\
\hline & & & $\begin{array}{l}\text { Body- } \\
\text { weight }\end{array}$ & $\begin{array}{c}\text { Pancreas } \\
\text { weight }\end{array}$ & $\begin{array}{l}\text { Body- } \\
\text { weight }\end{array}$ & $\begin{array}{c}\text { Pancreas } \\
\text { weight }\end{array}$ \\
\hline \multirow[t]{8}{*}{$\mathbf{I}$} & 20 & Raw & \multicolumn{2}{|c|}{ Not tested } & 239 & \\
\hline & ro & & \multirow{2}{*}{\multicolumn{2}{|c|}{ Not tested }} & & 0.80 \\
\hline & 19 & Heated & & & 285 & \\
\hline & 10 & & & & 0.33 \\
\hline & 19 & $\begin{array}{l}\text { Raw, with } \\
0.3 \% \text { DL- } \\
\text { methionine }\end{array}$ & \multicolumn{2}{|c|}{ Not tested } & 235 & \\
\hline & 5 & & \multirow{2}{*}{\multicolumn{2}{|c|}{ Not tested }} & & 0.80 \\
\hline & 20 & $\begin{array}{l}\text { Heated, with } \\
0.3 \% \text { DL- } \\
\text { methionine }\end{array}$ & & & 260 & \\
\hline & 5 & & & & & 0.34 \\
\hline \multirow[t]{2}{*}{2} & 9 & Raw & 238 & 0.64 & 178 & 0.73 \\
\hline & 9 & Heated & 263 & 0.30 & 232 & 0.32 \\
\hline \multirow[t]{2}{*}{3} & ro & Raw & 222 & 0.87 & I 84 & 0.96 \\
\hline & 10 & Heated & 254 & 0.32 & 233 & 0.36 \\
\hline \multirow[t]{2}{*}{4} & IO & Raw & 196 & 0.98 & I6I & $\mathbf{I} \cdot 07$ \\
\hline & IO & Heated & 233 & 0.32 & 217 & 0.37 \\
\hline $\begin{array}{l}\text { Mean } \\
\text { (Expts }\end{array}$ & & Raw & 219 & 0.83 & I 74 & 0.93 \\
\hline $2-4)$ & & Heated & 250 & 0.31 & 227 & 0.35 \\
\hline
\end{tabular}


weight of a representative group of birds from each treatment was significantly $(0.001<P<0.01)$ greater. The addition of extra methionine to the diet had no effect on either.

Three comparisons were made of the effects of the raw and heated meals in germfree and conventional chicks, and the results were pooled for statistical analysis. Body-weights of the germ-free birds were significantly $(P<0.001)$ greater than those of conventional birds. The weights achieved on the diets with raw soya meal were highly significantly $(P<0.00 \mathrm{r})$ less than those on diets with heated meal but the depression in growth was significantly $(0.01<P<0.05)$ more severe in the conventional than in the germ-free environment. All the birds given raw soya meal had enlarged pancreases, but there was no difference between pancreas weights in the two environments.

\section{Analysis of gut contents}

The gut contents from the birds in Expt 2 were separated into their soluble and insoluble components and the total $\mathrm{N}$ was determined. The results (expressed as $\mathrm{mg} / \mathrm{ro0} \mathrm{g}$ body-weight) are given in Tables 3 and 4 . In general the amount of insoluble matter in the segments distal to the duodenum was greater in the birds given raw soya; the total $\mathrm{N}$ content followed a similar pattern. No marked differences could be seen in the distribution of soluble matter. The soluble contents were separated on

Table 3. Dry weight (mg/100 g body-zweight) and nitrogen content ( $\mathrm{mg} / \mathrm{ro0} \mathrm{g}$ body-zeight) of insoluble fraction of gut contents from germ-free and conventional chicks reared to 3 weeks on diets containing raw or heated soya-bean meal

(Dry weights are means with standard errors for five chicks; values for $\mathrm{N}$ content are the results of determinations on the pooled samples from five chicks)

\begin{tabular}{|c|c|c|c|c|c|c|c|c|}
\hline \multirow[b]{3}{*}{ Gut segment } & \multicolumn{4}{|c|}{ Germ-free chicks } & \multicolumn{4}{|c|}{ Conventional chicks } \\
\hline & \multicolumn{2}{|c|}{ Raw soya } & \multicolumn{2}{|c|}{ Heated soya } & \multicolumn{2}{|c|}{ Raw soya } & \multicolumn{2}{|c|}{ Heated soya } \\
\hline & $\begin{array}{c}\text { Dry } \\
\text { weight }\end{array}$ & $\begin{array}{c}\mathrm{N} \\
\text { content }\end{array}$ & $\begin{array}{c}\text { Dry } \\
\text { weight }\end{array}$ & $\underset{\text { content }}{\mathrm{N}}$ & $\begin{array}{c}\text { Dry } \\
\text { weight }\end{array}$ & $\begin{array}{c}\mathrm{N} \\
\text { content }\end{array}$ & $\begin{array}{c}\text { Dry } \\
\text { weight }\end{array}$ & $\underset{\text { content }}{\mathrm{N}}$ \\
\hline Duodenum & $8 \pm 2$ & 0.28 & $7 \pm 0.8$ & 0.3 & $5 \pm \mathbf{I}$ & 0.14 & $8 \pm 2$ & 0.49 \\
\hline Jejunum & $124 \pm$ I I & $6 \cdot 6$ & $90 \pm 13$ & $4 \cdot 1$ & $103 \pm 9$ & $3 \cdot 9$ & $123 \pm 15$ & $6 \cdot 3$ \\
\hline Ileum & $130 \pm 19$ & $7 \cdot 1$ & $67 \pm 13$ & $\mathrm{I} \cdot 4$ & $138 \pm 19$ & $6 \cdot 9$ & $79 \pm 18$ & $2 \cdot 8$ \\
\hline Caecums and colon & $36 \pm 8$ & $2 \cdot I$ & $33 \pm 14$ & 0.7 & II \pm 22 & $10 \cdot 0$ & $52 \pm 4$ & $3 \cdot 0$ \\
\hline
\end{tabular}

Table 4. Nitrogen content (mg/roo $\mathrm{g}$ body-weight) of soluble fractions of gut contents of germ-free and conventional chicks reared to 3 weeks on diets containing raw or heated soya-bean meal

(Values are the results of determinations on the pooled samples from five chicks)

\begin{tabular}{|c|c|c|c|c|}
\hline \multirow[b]{2}{*}{ Gut segment } & \multicolumn{2}{|c|}{ Germ-free chicks } & \multicolumn{2}{|c|}{ Conventional chicks } \\
\hline & Raw soya & Heated soya & Raw soya & Heated soya \\
\hline Duodenum & 0.46 & 0.32 & 0.50 & 0.25 \\
\hline Jejunum & $5 \cdot 8$ & $3 \cdot 9$ & $2 \cdot 5$ & $4 \cdot 8$ \\
\hline Ileum & 3.0 & $5 \cdot 3$ & 3.7 & $3 \cdot 3$ \\
\hline Caecums and colon & $4 \cdot 6$ & $2 \cdot 9$ & $7 \cdot 8$ & 4.3 \\
\hline
\end{tabular}


Table 5. Amounts of 'proteins', 'peptides' and 'free amino acids' (in mg leucine equivalents/mg nitrogen) in the pooled soluble contents from different segments of the gut of germ-free and conventional chicks reared to 3 weeks on a diet containing raw or heated soya-bean meal

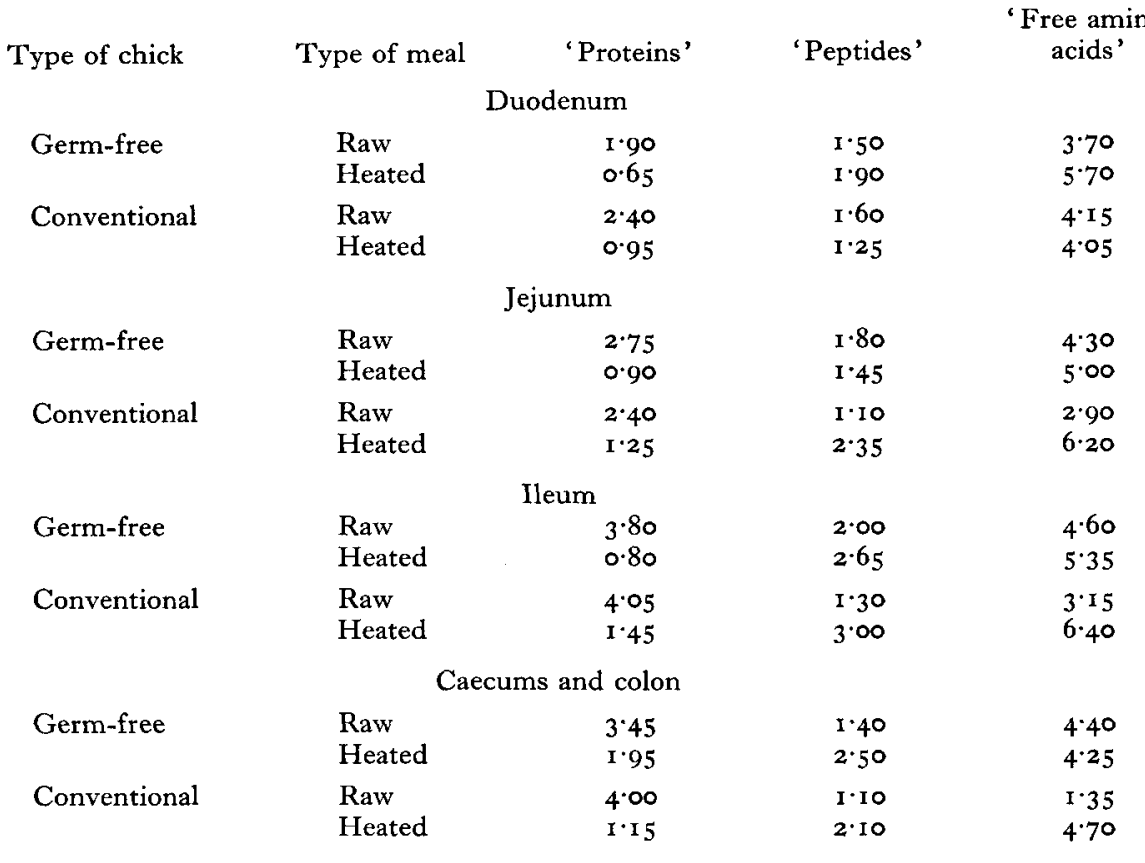

Table 6. Enzyme content of the pancreases of 3-week-old conventional chicks given diets containing raw or heated soya-bean meal

(Means with standard errors for five birds)

\begin{tabular}{|c|c|c|c|c|}
\hline Type of soya & $\begin{array}{l}\text { Total } \\
\text { proteolytic } \\
\text { activity } \\
\text { (m-moles } \\
\text { tyrosine/h) }\end{array}$ & $\begin{array}{l}\text { Chymotrypsin } \\
\text { activity } \\
\text { (units*) }\end{array}$ & $\begin{array}{l}\text { Trypsin } \\
\text { activity } \\
\text { (units*) }\end{array}$ & $\begin{array}{c}\alpha \text {-Amylase } \\
\text { activity } \times 10^{-5} \\
(\mu \mathrm{g} \text { maltose } / \mathrm{h}\end{array}$ \\
\hline \multicolumn{5}{|c|}{ Activity/g pancreas } \\
\hline $\begin{array}{l}\text { Raw } \\
\text { Heated } \\
\text { Raw }+ \text { methionine } \\
\text { Heated +methionine } \\
\text { Control }\end{array}$ & 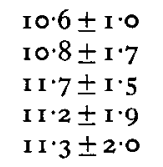 & $\begin{array}{l}59 \cdot 4 \pm 7 \cdot 1 \\
75 \cdot 1 \pm 20 \cdot 0 \\
\text { Not tested } \\
\text { Not tested } \\
64 \cdot 4 \pm 15 \cdot 0\end{array}$ & $\begin{array}{l}49 \cdot 7 \pm 7 \cdot 1 \\
46 \cdot 3 \pm 7 \cdot 5 \\
\text { Not tested } \\
\text { Not tested } \\
48 \cdot 8 \pm 14 \cdot 4\end{array}$ & $\begin{array}{r}42 \cdot 3 \pm 8 \cdot 4 \\
106 \cdot 3 \pm 16 \cdot 8 \\
48 \cdot 4 \pm 14 \cdot 6 \\
78 \cdot 8 \pm 16 \cdot 0 \\
49 \cdot 1 \pm 21 \cdot 1\end{array}$ \\
\hline \multicolumn{5}{|c|}{ Total activity/pancreas } \\
\hline $\begin{array}{l}\text { Raw } \\
\text { Heated } \\
\text { Raw }+ \text { methionine } \\
\text { Heated + methionine } \\
\text { Control }\end{array}$ & $\begin{array}{l}29 \cdot 9 \pm 6 \cdot 4 \\
13 \cdot 4 \pm 3 \cdot 9 \\
32 \cdot 9 \pm 6 \cdot 6 \\
13 \cdot 8 \pm 2 \cdot 3 \\
15 \cdot 3 \pm 3 \cdot 6\end{array}$ & $\begin{array}{l}162 \pm 4 \mathrm{I} \\
87 \pm 2 \mathrm{I} \\
\text { Not tested } \\
\text { Not tested } \\
66 \pm 19\end{array}$ & $\begin{array}{l}\text { I } 12 \pm 22 \\
54 \pm 9 \\
\text { Not tested } \\
\text { Not tested } \\
51 \pm 24\end{array}$ & $\begin{array}{r}117 \pm 26 \\
125 \pm 14 \\
136 \pm 43 \\
98 \pm 23 \\
50 \pm 20\end{array}$ \\
\hline
\end{tabular}

* A unit of chymotrypsin or trypsin activity gives a change of $\mathrm{I} \cdot \circ$ optical density/min. 
a Sephadex column into 'protein', 'peptide' and 'amino acid' fractions, with the results given in Table 5 . In the jejunum and ileum there was a considerably higher amount of 'protein', with correspondingly less 'peptide' and 'amino acid', in the contents from the birds given raw meal. The pattern of distribution in the ileum is illustrated in Fig. I. In none of these analyses was any marked difference observed between germ-free and conventional birds.

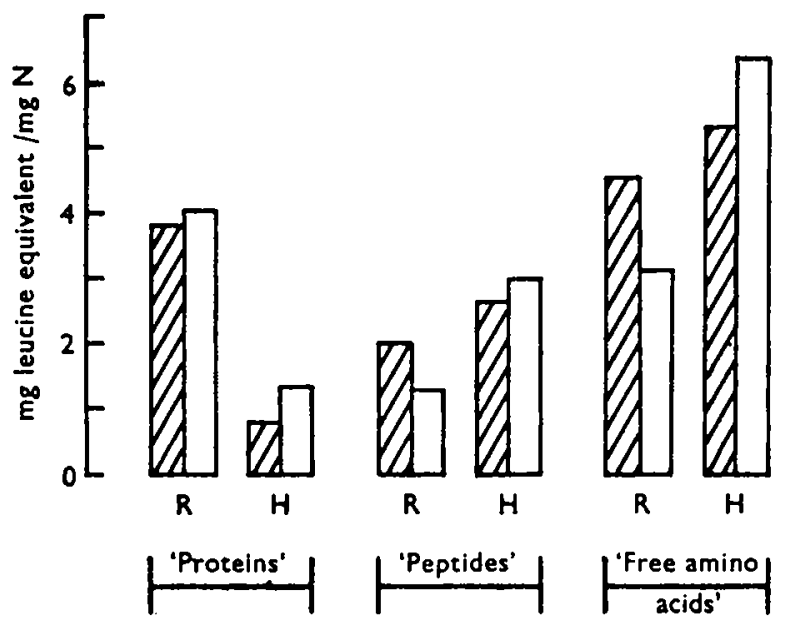

Fig. I. 'Protein', 'peptide' and 'free amino acid ' concentrations (in mg leucine equivalents/mg nitrogen) in the pooled soluble fractions of the contents from the ileum of germ-free $(\mathbb{Z})$ and conventional $(\square)$ chicks reared to 3 weeks on a diet containing raw (R) or heated $(H)$ soya-bean meal.

\section{Enzyme content of the pancreas}

For comparison, values are included from a group of five birds given an ordinary chick starter mash containing no soya. The results of the pilot experiment with conventional chicks are summarized in Table 6.

Although the concentration of proteolytic activity, calculated per $\mathrm{g}$ pancreas, was similar in all groups, the total proteolytic activity was greatly elevated in the birds given raw soya meal, and the increase was shown both in the trypsin and chymotrypsin fractions. Conversely, although the concentration of $\alpha$-amylase was less in pancreases from birds given raw soya, the total amount was much the same in all birds given the soya diets. The addition of methionine had no substantial effect on enzyme activities. The pancreases from birds given the chick starter mash showed proteolytic activities comparable with those from birds given the heated soya diets, but their $\alpha$-amylase activity was much lower.

Pancreases were taken from all birds, germ-free and conventional, in Expt 4. The trypsin and $\alpha$-amylase activities, per $g$ pancreas and in the whole gland, were determined with the results given in Table 7. On this occasion both the concentration and the total amount of trypsin were higher in the pancreases from birds given raw soya. When calculated in terms of total pancreatic activity the increase was much greater in the conventional chicks, and the difference in response in the two environments was significant at $P<0.001$ (calculated by Student's $t$ test, with 18 degrees of freedom). 
The results with $\alpha$-amylase followed a similar pattern to that of the previous experiment, in that the concentrations were lower in the pancreases from chicks given raw soya but the total amounts were roughly comparable on both diets. There was no marked difference between germ-free and conventional birds.

Table 7. Trypsin and $\alpha$-amylase activities of the pancreases of 3-week-old germ-free and conventional chicks given diets containing raw or heated soya-bean meal

\begin{tabular}{|c|c|c|c|}
\hline \multirow[b]{2}{*}{ Type of chick } & \multirow{3}{*}{ Type of soya } & rors for ten birds) & \\
\hline & & $\begin{array}{l}\text { Trypsin activity } \\
\text { (units*) }\end{array}$ & $\begin{array}{c}\alpha \text {-Amylase activity } \\
\text { (g starch } \\
\text { hydrolysed/h) }\end{array}$ \\
\hline & & \multicolumn{2}{|c|}{ Activity/g pancreas } \\
\hline Germ-free & $\begin{array}{l}\text { Raw } \\
\text { Heated }\end{array}$ & $\begin{array}{l}39 \cdot 6 \pm 2 \cdot 4 \\
21 \cdot 8 \pm 2 \cdot 4\end{array}$ & $\begin{array}{l}117 \pm 26 \\
371 \pm 42\end{array}$ \\
\hline \multirow[t]{2}{*}{ Conventional } & $\begin{array}{l}\text { Raw } \\
\text { Heated }\end{array}$ & $\begin{array}{l}62 \cdot 4 \pm 3 \cdot 4 \\
23 \cdot 4 \pm 2 \cdot 6\end{array}$ & $\begin{array}{l}182 \pm 30 \\
362 \pm 53\end{array}$ \\
\hline & & \multicolumn{2}{|c|}{ Total activity/pancreas } \\
\hline Germ-free & $\begin{array}{l}\text { Raw } \\
\text { Heated }\end{array}$ & $\begin{array}{l}76 \cdot 0 \pm 6 \cdot 4 \\
16 \cdot 6 \pm 2 \cdot 4\end{array}$ & $\begin{array}{l}241 \pm 64 \\
280 \pm 3^{8}\end{array}$ \\
\hline Conventional & $\begin{array}{l}\text { Raw } \\
\text { Heated }\end{array}$ & $\begin{array}{r}107 \cdot 8 \pm 9 \cdot 6 \\
18 \cdot 2 \pm 1 \cdot 8\end{array}$ & $\begin{array}{l}331 \pm 65 \\
281 \pm 36\end{array}$ \\
\hline
\end{tabular}

\section{DISCUSSION}

There is ample evidence from many laboratories that the growth of chicks given diets containing raw soya meal is greatly inferior to that attained on similar diets containing the corresponding heated meal and, furthermore, that the pancreases of the birds given raw soya are grossly enlarged. The detrimental effects of raw soya beans are generally ascribed to their content of heat-labile 'toxic' factors, notably trypsin inhibitor(s) and haemagglutinin(s). Both the effects of raw soya were evident in all the experiments reported here, but its growth-depressing action was less severe in germ-free than in conventional chicks. In each of three separate comparisons the body-weights attained at 3 weeks by the conventional chicks given the diet with raw soya were smaller than those of their germ-free counterparts, and when the combined results were analysed statistically this difference in growth depression was significant at $0.01<P<0.05$. There was, however, no difference in the degree of pancreatic enlargement in the two environments. These results confirm the report of Miller \& Coates (1966) and lend further weight to their suggestion that the microflora of the alimentary tract plays an important role in the growth-depressing action of raw soya meal. Other workers have shown that supplementation of diets containing raw soya with antibiotics partially alleviates the growth depression in rats (Barnes, Kwong \& Fiala, I965), chicks (Braham, Bird \& Baumann, I959) and poults (Linerode, Waibel \& Pomeroy, 196I), an effect that might also be explained in terms of a modification of the gut microflora.

Consideration of the properties of the heat-labile components of raw soya beans gives rise to several hypotheses regarding ways in which the depressing effect on 
growth might be exacerbated by microbial action. One possibility is that the haemagglutinin(s), or some other component, are not toxic per se but are converted into toxins by microbial action in the gut. This type of reaction has been demonstrated in the case of cycasin, a glycoside that becomes carcinogenic after degradation to its aglycone by bacterial $\beta$-glucosidase (Spatz, McDaniel \& Laqueur, 1966). Others concern the trypsin inhibitors, the presence of which is likely to result in poorer digestion of protein. It could be postulated that the germ-free bird may be better able to utilize the products of digestion of the raw meal. It has also been suggested that impaired protein digestion due to trypsin inhibition might alter the composition of the contents, and hence the balance of micro-organisms, in the alimentary tract (Jayne-Williams \& Coates, I 969 ). It is generally assumed that pancreatic enlargement is a compensatory mechanism to overcome the inhibition of trypsin by raw soya. However, if the inhibition were not fully overcome, accumulation of undigested protein would be inevitable; this in turn might encourage establishment of proteolytic anaerobes that could be implicated in the depression of growth. The present investigations were designed to test the plausibility of this argument.

Our findings on the proteolytic enzymes agree with those of Chernick, Lepkovsky \& Chaikoff (1948) and Applegarth, Furuta \& Lepkovsky (1964), who observed enlarged pancreases, containing increased amounts of proteolytic enzymes, in chicks given diets containing raw soya-bean meal. In our exploratory experiments with conventional birds only, the total proteolytic activity of the pancreases from birds given raw soya was about double that of similar tissue from their hatchmates given heated soya, although the concentration was much the same in both. Trypsin and chymotrypsin activities followed a similar pattern. Conversely, amylase activity was greater per $\mathrm{mg}$ tissue in the heated soya group, but when calculated per whole pancreas was similar in chicks given heated or raw soya. The increase in pancreatic chymotrypsin activity could be the response to the presence of a specific chymotrypsin inhibitor which was isolated by Birk (1961) from raw soya meal. However, since trypsin is concerned in the activation of chymotrypsinogen, inhibition of trypsin could itself result in a deficiency of chymotrypsin activity. The similarity in total amylolytic activity in the pancreases from birds given raw or heated meal is not surprising, since trypsin is not involved in the release of $\alpha$-amylase from zymogen nor is there any recorded evidence for the presence of an amylase inhibitor in raw soya. Kakade, Barton, Schaible \& Evans (1967) also failed to detect any differences in total amylase activity in the pancreases from chicks given either type of soya.

In the comparison between germ-free and conventional chicks the total amylolytic activity was again similar in normal and enlarged pancreases, and was apparently unaffected by the environment. Trypsin was the only proteolytic enzyme measured on that occasion. Since the conditions of the assay method were different from those in Expt I no quantitative comparison is possible, but qualitatively the results were similar. There was an even greater increase in trypsin activity in pancreases from the birds given raw soya and the concentration as well as activity per whole pancreas, was higher. There was no difference in pancreatic trypsin activity between germ-free and conventional chicks given heated soya but the increase in activity on the raw soya 
diet was significantly $(P<0.001)$ greater in the conventional group. No explanation can be advanced for this finding until it has been further investigated. The assay depends on preliminary activation of the proteolytic enzymes by enterokinase and it is possible that the apparently greater amounts found in conventional birds may reflect a difference in response to the activator, or to some other step in the assay procedure, rather than a true increase in enzyme content. Work is in hand to examine these possibilities.

It cannot be assumed that the proteolytic activity of the pancreas necessarily reflects the amount of proteases secreted into the small intestine. No attempt was made to determine proteolytic enzymes in the intestinal tract since the presence of trypsin inhibitors in the gut contents of birds given raw soya would have invalidated the results. In spite of the increased production of proteolytic enzymes in the pancreas, protein digestion was apparently less efficient in the chicks receiving the raw soya diet since relatively larger amounts of insoluble matter, with higher $\mathrm{N}$ contents, were present in the gut contents, particularly in the jejunum and ileum. Furthermore, separation on Sephadex gel of the soluble fraction of the contents of the alimentary tract showed a greater proportion of $\mathrm{N}$ present as 'protein', with correspondingly less 'peptide' and 'amino acids' in the chicks fed on the raw soya diet. This difference was also mainly evident in the jejunum and ileum, but not consistently in the duodenum or caecums and colon. The effect was not noticeably different in germ-free and conventional birds, which is perhaps surprising in view of the greater amount of proteolytic activity in the pancreases of conventional compared with germ-free chicks. Even if the extra amounts of proteases produced by the enlarged pancreases were secreted into the small intestine, they were apparently insufficient in either environment to counteract fully the anti-trypsin activity in the raw meal.

From the results of Miller \& Coates (1966) and those given in Table 2 it is clear that, even in a germ-free environment, growth of chicks is poorer on a diet containing raw in place of heated soya meal. Thus part of the deterimental effect of the raw product must be independent of microbial action, but it is not yet clear whether the greater growth depression in conventional birds is the sum of two separate reactions, one of them mediated through the gut microflora, or whether a primary non-microbial effect is exacerbated by the presence of micro-organisms. In the light of our findings so far, the hypothesis that an altered microbial population may result from inefficient protein digestion still seems tenable. Although there was a greater production of proteolytic enzymes by the birds given the raw soya, nevertheless there was evidence of impaired protein digestion; a detailed bacteriological examination would be necessary to determine whether or not the microbial population is thereby altered and, if so, whether the organisms concerned affect chick growth. Since a greater ratio of protein $\mathrm{N}$ to $\alpha$-amino- $\mathrm{N}$ was found in the gut contents of the raw soya groups in both environments it seems unlikely that the better growth of germ-free chicks can be attributed to more efficient digestion, particularly as they showed a smaller increase than their conventional controls in proteolytic activity of the pancreas. It is, however, possible that the products of digestion are better utilized in the absence of a gut microflora, although our preliminary (unpublished) studies of digestibility and net 
protein utilization do not indicate that this is so. There remains the possibility of increased toxicity due to microbial action on one of the other heat-labile components of raw soya, and this aspect of the problem is currently under investigation.

We are grateful to our colleagues Dr R. C. Siddons for valuable advice and help with the enzyme assays and Dr D. J. Jayne-Williams for sterility checks on the germ-free birds. We also thank British Oil and Cake Mills Ltd, London, and Central Soya, Decatur, Indiana, USA for generous gifts of soya beans and meal.

\section{REFEREN CES}

Applegarth, A., Furuta, F. \& Lepkovsky, S. (1964). Poult. Sci. 43, 733.

Barnes, R. H., Kwong, E. \& Fiala, G. (1965). F. Nutr. 85, 123.

Birk, Y. (196r). Biochim. biophys. Acta 54, 378.

Braham, J. E., Bird, H. R. \& Baumann, C. A. (1959). F. Nutr. 67, I49.

Chernick, S. S., Lepkovsky, S. \& Chaikoff, I. L. (1948). Am. F. Physiol. 155, 33.

Coates, M. E., Fuller, R., Harrison, G. F., Lev, M. \& Suffolk, S. F. (1963). Br. 7. Nutr. I7, I41.

Dollar, A. M. (1959). Biochemical studies of nutrition in the ruminant. PhD Thesis, University of Reading.

Ford, J. E. (1965). Br. F. Nutr. 19, 277.

Howard, F. \& Yudkin, J. (1963). Br. F. Nutr. 17, 28r.

Jayne-Williams, D. J. \& Coates, M. E. (1969). In International Encyclopaedia of Food and Nutrition. Vol. I7, Part I, p. 241. Oxford: Pergamon Press.

Kakade, M. L., Barton, T. L., Schaible, P. J. \& Evans, R. J. (1967). Poult. Sci. 46, I 578.

Kunitz, M. (1 947). F. gen. Physiol. 30, 291.

Liener, I. E. (1962). Am. F. clin. Nutr. Ix, 28r.

Linerode, P. A., Waibel, P. E. \& Pomeroy, B. S. (I961). F. Nutr. 75, 427.

Miller, W. S. \& Coates, M. E. (I966). Proc. Nutr. Soc. 25, iv.

Moore, S. \& Stein, W. H. (1954). F. biol. Chem. 211, 907.

Nelson, N. (1944). 7. biol. Chem. 153, 375.

Schwert, G. W. \& Takenaka, Y. (1955). Biochim. biophys. Acta 16, 570.

Somogyi, M. (1952). F. biol. Chem. 195, I 9.

Spatz, M., McDaniel, E. G. \& Laqueur, G. L. (1966). Proc. Soc. exp. Biol. Med. 121, 417. 